\title{
Investigation and management of water pollution sources in Cameron Highlands, Malaysia
}

\author{
M. Eisakhani ${ }^{1}$, A. Pauzi ${ }^{1}$, O. Karim ${ }^{1}$ \& A. Malakahmad ${ }^{2}$ \\ ${ }^{1}$ Universiti Kebangsaan Malaysia (UKM), Malaysia \\ ${ }^{2}$ Universiti Teknologi PETRONAS (UTP), Malaysia
}

\begin{abstract}
The water quality of rivers in Cameron Highlands has deteriorated significantly due to land clearing for agriculture, excessive usage of pesticides and fertilizers as well as construction activities in rapidly developing urban areas. It has been investigated that non-point pollution sources (NPSs) are the main contributor of this water quality drop. NPSs are diverse and hard to identify and therefore they are difficult to estimate. Therefore, Geographical Information Systems (GIS) was used to provide an extensive approach to evaluate land use and other mapping characteristics to explain the spatial distribution of NPSs of contamination in Cameron Highlands. The method to assess pollution sources has been developed using Cameron Highlands Master Plan (2006-2010) for integrating GIS databases, as well as pollution loads in the area of study. The results show highest annual runoff is created by forest, $3.56 \times 10^{8} \mathrm{~m}^{3} / \mathrm{yr}$ followed by urban development, $1.46 \times 10^{8} \mathrm{~m}^{3} / \mathrm{yr}$. Furthermore, urban development causes highest BOD load $\left(1.31 \times 10^{6} \mathrm{kgBOD} / \mathrm{yr}\right)$ while agricultural activities and forest contribute the highest annual loads for phosphorus $\left(6.91 \times 10^{4} \mathrm{kgP} / \mathrm{yr}\right)$ and nitrogen $\left(2.50 \times 10^{5} \mathrm{kgN} / \mathrm{yr}\right)$, respectively. Therefore, Non-structural management was recommended for the study area, which includes establish and provide technical advisory services unit, develop demonstration farms and provide incentives to encourage farmers in implementing sustainable agricultural management practices.
\end{abstract}

Keywords: water pollution sources, non-structural management, Cameron Highlands. 


\section{Introduction}

Cameron Highlands is one of the major highland areas in Peninsular Malaysia and plays a vital role in providing water supply for this area. The area of Cameron Highlands is drained by eight rivers with Bertam, Telom, and Lemoi Rivers being the major ones with 123 tributaries [1]. Cameron Highlands is characterized on one hand by undisturbed nature with virgin and original mountain forest streams of ecological and chemical outstanding quality. On the other hand intensive agriculture and urbanization causes pollution problems in this most vulnerable part of the catchment [2]. Water pollutants are classified as "point" and "non-point" sources [3]. Point sources can be identified as all dry weather pollutants that enter the river or stream through pipes or channels. Point sources are easily identified and pollutant concentrations can be easily measured through in-situ and ex-situ methods [4].

Non-point source pollution is generally not recognized until the mid-1960s. Initially, non-point source pollution was associated entirely with pollution from storm water and runoff. Subsequently, non-point source pollution expanded to encompass all forms of diffuse pollutants. Non-point pollutants are defined as contaminants of surface and subsurface soil and water resources that are diffused in nature and cannot be traced to a point location [5]. Characterizing pollutants requires extensive knowledge of the areas' geography and non-point sources, therefore the diffuse (non-point) sources of pollution must be identified and located in order to be assessed [6]. Non-point pollution models are basically a description of the hydrologic rainfall-runoff transformation processes with attached quality components [7]. Non-point sources are derived from activities on extensive units of land, originating from urban runoff, construction, hydrologic modification, mining, agriculture, irrigation return flows, solid waste disposal, atmospheric deposition, stream bank erosion, and individual sewage disposal [8].

Nutrient (nitrogen and phosphorus) loading in water bodies can cause eutrophication of streams and is characterized by excessive plant growth, dense algal growth, and results in diurnal fluctuations in dissolved oxygen levels due to algal oxygen consumption during growth and bacterial consumption of oxygen in the decaying process of dead algae and plant material. Excessive plant growth can cause oxygen depletion, odour problems, fish kill, and photosynthetic deprivation [9]. When elevated levels of BOD lower the concentration of dissolved oxygen, there can be profound effects on the water body itself as well as the prevailing aquatic life. Low oxygen concentration causes great stress to aquatic life. Dissolved oxygen (DO) fluctuations act as a stressor on DO sensitive species. Eventually species sensitive to low DO levels are replaced by species that are more tolerant [10].

Geographic Information System (GIS) is one of the approaches which can be used to study non-point pollution. GIS is a computer system capable of spatially representing data on the land surface and linking additional data related to this spatial depiction, through tables and charts. Furthermore, GIS is used in the area of environmental modelling, by providing ease and accuracy in surface terrain 
representation, watershed delineation, precipitation, data compilation, non-point source pollutant loading calculation and other concepts related to environmental processes. Consequently GIS has emerged as a powerful modelling tool which can help provide the necessary knowledge to make management decisions [10]. In recent years, the use of GIS has increased in order to identify and assess erosion and non-point pollution. A GIS can combine automated cartographic features with database management capabilities as shown in Fig. 1 [6].

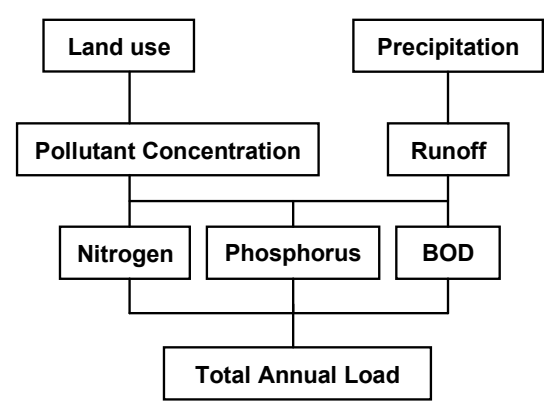

Figure 1: $\quad$ Non point source pollution model.

In this study an ArcView GIS application has been developed for the assessment of recognized non-point sources of pollution in Cameron Highlands. The method makes use of available elevation data, stream network, rainfall, discharges and land use data sets of the Cameron Highlands for the estimation of average annual pollutant loads in form of total nitrogen and phosphorus as well as biochemical oxygen demand (BOD).

\section{Experimental details}

\subsection{Identification of non-point sources of pollution}

Data collection: The location and identification of the types of non-point sources of pollution was carried out via ground work of collecting primary data. Some data on the development of the area was obtained from the authorities in Cameron Highlands. In addition, the future development of the area of study was considered according to the Cameron Highlands master plan (2006 - 2010).

Processing of the Data: Digitized Peninsular Malaysia map was exploited in GIS system. The map allows the user to find places for the desired features and to locate point of action. Then, geographical coordinates (latitude and longitude) were assigned to the spots located depending on the analytical method used for the location. Observations were conducted at the located coordinates. The results could then be displayed as a digital map, printed as a paper map or combined with spreadsheet-like tables and charts. 


\subsection{Land use}

The term land use describes the prevailing activity taking place in a uniform demographic area. Therefore, according to Naranjo [6] land uses was categorized according to homogeneous characteristics because land use has a direct effect on the water quality. Based on the existing land use information, different activities in the area of study were observed and land use classification was carried out for the region.

\subsection{Pollution loads calculation}

The following four steps define the procedure for calculating pollution loads generated by non-point sources:

1. Estimate typical concentrations of each water quality parameter in runoff based on Cameron Highlands Master Plan (2006 - 2010).

2. These water quality data, defined as estimated mean concentrations (EMC), was derived from each pre-defined land use type.

3. Load from a given geographic location was calculated by multiplying the calculated runoff volume from that area with the appropriate EMC value.

4. Total loads from a watershed were calculated by summing the loads from all the contributing areas in the watershed.

\subsection{Water quality parameters}

Three water quality parameters have been selected for quantification of nonpoint pollution sources [12].

- Total nitrogen $(\mathrm{TN})=$ all the various forms of inorganic and organic nitrogen

- Total phosphorus (TP) = orthophosphate and organic phosphorus

- Biochemical Oxygen Demand $(B O D)=$ measure of biodegradable organics in the water

\subsection{Runoff coefficients}

In order to assess the transport of pollutants in a region, an understanding of the means by which the loads migrate is required. Non-point source pollutants are carried over land and into the river network of a region by direct runoff. According to Chow [13] after the extent of the watershed has been determined, it is necessary to obtain an average runoff volume generated. Moreover, a relative measure of the urbanization of an area is provided by runoff coefficients, by assigning high values to paved areas and low values to open, grassy lands. The total runoff for a given watershed could be calculated by multiplying the total rainfall by the runoff coefficients in that particular watershed. The coefficients shown in Table 1 were chosen from available literature and were assigned to each land use [14]. 
Table 1: $\quad$ Runoff coefficients per land use.

\begin{tabular}{|c|c|}
\hline Land use & Runoff Coefficient \\
\hline Urban & 0.89 \\
Vacant land & 0.22 \\
Agriculture & 0.24 \\
Barren & 0.22 \\
Wetlands & 0.80 \\
Residential & 0.34 \\
Water & 1.00 \\
Forest & 0.15 \\
\hline
\end{tabular}

\subsection{Estimated mean concentrations}

Estimated Mean Concentrations (EMCs) are typical pollutant values found in the runoff. These EMC values are assumed to be directly related to land uses in the drainage areas and constant independently of the duration and intensity of the rainfall events. The land use would be associated to a concentration database (Table 2) [14].

Table 2: $\quad$ Estimated mean concentration of pollutants in runoff (mg/l).

\begin{tabular}{|c|c|c|c|}
\hline Land use category & $\mathrm{TN}^{*}$ & $\mathrm{TP}^{* *}$ & $\mathrm{BOD}$ \\
\hline High Density Urban & 1.34 & 0.32 & 9 \\
Residential & 1.82 & 0.57 & 15 \\
Agricultural & 4.40 & 1.30 & 4 \\
Vacant land & 1.51 & 0.12 & 6 \\
Forest & 0.70 & 0.01 & 6 \\
Wetlands & 0.83 & 0.06 & 6 \\
Water & 0.00 & 0.00 & 0 \\
Barren & 5.20 & 0.59 & 13 \\
\hline
\end{tabular}

*TN: Total Nitrogen

**TP: Total Phosphorus

Loads for total nitrogen, total phosphorus, and BOD can be estimated by applying pollutant concentrations to annual runoff volumes. The runoff was calculated using eq. (1). Then load for each pollutant was calculated by the runoff information as well as estimated mean concentration values in runoff based on the eq.(2).

$$
\begin{gathered}
\text { Runoff }=\text { subcatchment area } \times \text { annual rainfall } \times \text { runoff coefficient } \\
\text { Load }=\text { runoff } \times \text { EMC }
\end{gathered}
$$

\section{Results and discussion}

The ArcView non-point extension works as an ArcView add-on extension and it requires the Spatial Analyst module as well. The Non-point extension estimates 
the total diffuse pollution generated by both human and natural activities and is able to calculate how much of it gets into the river system. In order to develop a simulation and monitoring program for the river basins in Cameron Highlands the non-point pollution model was used to estimate the total annual pollutant loadings into the river systems.

\subsection{Including the data in the model}

Land use: Based on the existing land uses in the area of study, a land use classification was carried out and a pollutant concentration database was generated for the region. Fig. 2 shows the Cameron Highlands location in Peninsular Malaysia map. While residential areas in the district of Cameron Highlands are characterized by low-density houses and just have the percentage of less than one, agriculture and forestry are two major land uses.

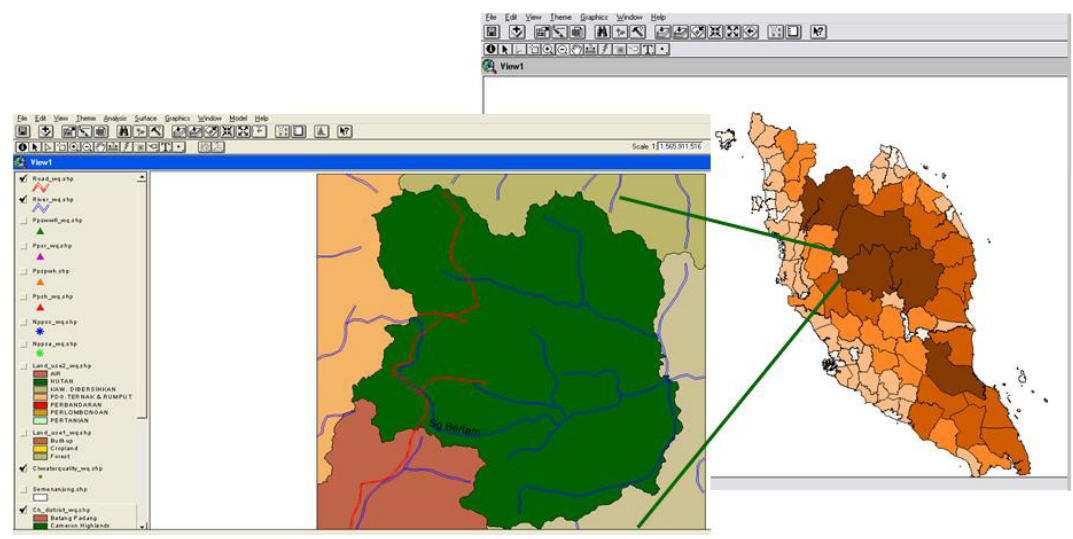

Figure 2: Digitized Peninsular Malaysia (right) and Cameron Highlands rivers network (left) map.

Vegetables and tea dominate the agriculture sector, while forestry is mainly made up of permanent reserved forest (PRF) and government vacant land. Agriculture is the main socio-economies activity in the highlands of study area. The cold and temperate weather makes the area most suitable for many agricultural products. Flower planting for example is one of the unique tourist attractions for the area. In addition, vegetables appropriate for cold weather such as cabbage, cauliflower, capsicum, asparagus, spring onion, lettuce, pak choy, celery, bean, sweet pea, carrot and short-term plants including strawberry and herbs as well as fruits including out-of-season fruits types of orange and tangerine can be found in the study area.

Commercial activities observed in the area are:

- Town hotels in shop lots, service apartment, cottage chalets, backpackers' lodges and resort hotels from chalet-type to high-rise.

- Banking facilities are mainly found in Tanah Rata.

- Existing petrol stations are located in Ringlet and Brinchang. 
- Service industries i.e. workshop and warehouses, are located in commercial premises of one-storey building and free-standing building and can be found off the main road in Ringlet and Brinchang and along the main road in agriculture-based centres.

- Business premises are also provided on the ground level of apartments.

- There is no major shopping centre in the study area. An abandoned project is found in the centre of Tanah Rata town.

- Sale and exhibition of flowers and plants are located at the nurseries and cultivation areas adjacent to the main road. Tea kiosks are introduced in tea plantations.

- Market garden stalls in Kea Farm are operating on road reserves.

The runoff concentration values from agricultural area and other land uses were joined to the appropriate digitized land use polygon. The model was supplied with expected mean runoff concentrations (EMC values) based on Cameron Highlands Master Plan (2006 - 2010) which is assumed to be directly related to land use in the catchment. These default values are typical concentrations of pollutants found in the runoff from each pre-defined land use. The mean runoff concentration values $(\mathrm{mg} / \mathrm{L})$ were joined to the appropriate polygon in the land use coverage. Henceforth the total pollution generated by each land use polygon was estimated. Runoff concentration values were then joined to the land use map and therefore an attribute database with all the nonpoint sources of pollution and runoff associated to the land uses was generated (Fig. 3).

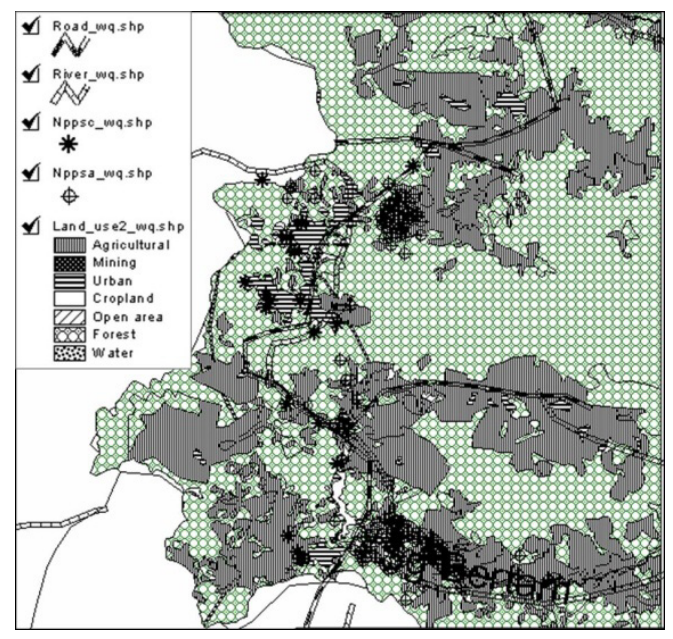

Figure 3: Cameron Highlands' land use map and non-point sources of pollution. 


\subsection{Pollution loads}

Runoff calculation: The pollutants were routed in the area of study and the total amount of pollution generated by the land uses as well as the domestic and industrial pollution that reach the river system was estimated. The rainfall data was obtained from Malaysia Meteorological Department (MMD) [15]. Then it was multiplied by related subcatchment land use and runoff coefficients as in Table 1 for each land use in Cameron Highlands (Table 3).

Table 3: $\quad$ Annual runoff per land use.

\begin{tabular}{|c|c|c|c|}
\hline Land use & $\begin{array}{c}\text { Area } \\
\text { (hectare) }\end{array}$ & $\begin{array}{c}\text { Annual } \\
\text { rainfall } \\
(\mathrm{mm} / \mathrm{yr})\end{array}$ & $\begin{array}{c}\text { Runoff } \\
\left(\mathrm{m}^{3} / \mathrm{yr}\right)\end{array}$ \\
\hline Urban & 4226.65 & & $1.46 \times 10^{8}$ \\
Agriculture & 5705.17 & & $5.31 \times 10^{7}$ \\
Vacant lands & 1.82 & 3880 & $1.55 \times 10^{4}$ \\
Water & 30.55 & & $1.19 \times 10^{6}$ \\
Forest & 61248.05 & & $3.56 \times 10^{8}$ \\
\hline Total & 71212.24 & & $5.57 \times 10^{8}$ \\
\hline
\end{tabular}

Given the runoff characteristics of the watershed, overland runoff can easily carry sediment, phosphorus, and nitrogen from the watershed into the stream reaches. The composition of the watershed indicates a mixture of rural and urban non-point sources which may contribute to the downstream impairment. Next, based on the annual runoff the BOD, Total nitrogen and total phosphorus pollution loads were calculated (Table 4).

Table 4: $\quad$ Annual pollution loads per land use.

\begin{tabular}{|c|c|c|c|}
\hline Land use & $\begin{array}{c}\text { Total } \\
\text { nitrogen } \\
\text { load }(\mathrm{kg} / \mathrm{yr})\end{array}$ & $\begin{array}{c}\text { Total } \\
\text { phosphorus } \\
\text { load } \\
(\mathrm{kg} / \mathrm{yr})\end{array}$ & $\begin{array}{c}\text { BOD } \\
\text { load } \\
(\mathrm{kg} / \mathrm{yr})\end{array}$ \\
\hline Urban & $1.96 \times 10^{5}$ & $4.67 \times 10^{4}$ & $1.31 \times 10^{6}$ \\
Agriculture & $2.34 \times 10^{5}$ & $6.91 \times 10^{4}$ & $2.13 \times 10^{5}$ \\
Vacant lands & $2.35 \times 10^{1}$ & $1.86 \times 10^{0}$ & $9.32 \times 10^{1}$ \\
Water & 0 & 0 & 0 \\
Forest & $2.50 \times 10^{5}$ & $3.56 \times 10^{3}$ & $2.14 \times 10^{6}$ \\
\hline
\end{tabular}

Results of this assessment reflect several areas of concern regarding non-point sources pollution in the Cameron Highlands and its rivers. Urban, forestry and agriculture are responsible for the largest proportions of NPSs of pollution in the watershed (Table 4).

Urban surface runoff can carry soil particles (minerals, organic matter and attached nutrients) and dissolved nutrients with it. Fertile cropland contains enough phosphorus to sustain crop growth for many years. Some of that same 
phosphorus can be carried away during heavy rains, dissolved in surface runoff or attached to soil particles. Surface runoff is the major pathway whereby phosphorus is lost from the soil to surface water, such as streams and rivers. Runoff from urbanized areas is more localized and can often be more severe in magnitude than agricultural runoff. Replacement of natural vegetation with pavement and removal of buffers reduces the ability of the watershed to filter pollutants before they enter surface waters. Water quality maintenance and control are normally achieved by implementing Best Management Practices (BMPs) to reduce extreme pollution problems and promote rapid recovery. The BMPs are intended to control activities in storm flow source areas and promote acceptable soil conservation practices.

A major human influence on nitrogen and phosphorus in the environment is the use of fertilizers in agricultural and urban areas. Commercial nitrogen fertilizers are applied either as ammonia or nitrate, but ammonia is rapidly converted to nitrate in the soil. Excess nitrate, not taken up by plants, can enter streams or seep down to ground water. Animal manure is also used as a nitrogen fertilizer. Organic nitrogen and urea in the manure are converted to ammonia and, ultimately, to nitrate in the soil. Phosphorus fertilizer generally is applied as a compound of phosphate. Phosphate is not very mobile in soil; it tends to remain attached to solid particles rather than dissolving in water. However, soil erosion can carry a considerable amount of particulate phosphate to streams. It can be shown by high amount of phosphorus load in agricultural sector of Cameron Highlands. Agriculture as the main economic activity in Cameron Highlands contributes very high eroded soils into rivers. The increase in soil erosion is related to the percentage of the total land use with increasing trend of land converted to agricultural lands.

\section{Management approaches}

This section examines the responses that local authorities could consider adopting when formulating policies to reduce the impacts of agriculture on water quality.

\subsection{Establish and provide the Cameron Highlands technical advisory services unit}

The local government or other related agencies should establish technical advisory services unit among the existing institutional setup, that give farmers free advice on soil erosion control, best available management on agricultural practices, sustainable land use practices and riparian management to avoid unnecessary discharges of excessive sediment loads into water.

\subsection{Develop demonstration farms in Cameron Highlands}

The Agricultural Department together with other related government agencies, such as Department of Irrigation and Drainage, Department of Environment, and Local Authorities should facilitate the development of a Monitored Farm to 
demonstrate environmentally sustainable methods of pastoral farming. The owners of the farm should work with the management committee involving farming community representatives, and representatives of the sponsoring organizations. A specific objective of the monitored farm project is the development of practical indicators for sustainable farming systems. The project should also include an extension program to encourage pastoral farmers to take up sustainable management practices. Information from the focus farms is to be transferred to other farmers in the area to raise awareness of sustainable management issues.

\subsection{Provide incentives to encourage farmers in implementing sustainable agricultural management practices}

The Government should provide a range of incentives to encourage sustainable management practices. The incentives can come in non-financial and financial approaches. The incentives should not be used to reward resource users for achieving an environmental bottom line or simply complying with legislation, they should be used to achieve positive environmental results over and above minimum acceptable standards.

\subsection{Economic methods}

The main economic methods for addressing non-point source pollution from agriculture are taxes, charges and subsidies. Taxes increase the private costs of farming to reflect the true value (monetary and non-monetary) of resources to the community, including the costs of pollution on the environment (the "social costs" of the resources). Subsidies are payments to encourage behavior that advances some public policy goal. They may be paid by an authority on behalf of the general public, or by the beneficiary of the activity.

\section{Conclusions}

The study was conducted to identify land use, non-point sources of pollution and their pollution loads into river system of Cameron Highlands using ArcView GIS. Considerable amounts of nitrogen, phosphorus and BOD load was observed based on different land uses especially agricultural activities. In addition, it was found that erosion due to land use alteration could cause more phosphorus release to the water bodies. While GIS-based non-points of pollution simulation have shown good performance to estimate different pollution loads, it is found as a suitable method for small basin areas because monitoring land cover conditions in a large extent of areas is not easy. Therefore, it could be suggested that for large area some other methods such as remote sensing method are more reasonable. Finally best management practices including structural and nonstructural methods would be practiced to reduce the pollution level in the area of study. 


\section{References}

[1] Van der ENT, A. \& Termeer, C., Study on river water quality of the Upper Bertam catchment. Saxion University, Deventer, Institute of Spatial Planning and Environmental Science, 2005.

[2] Hashim, A. \& Rahaman, G.M., Soil erosion and water pollution in Cameron Highlands: conservation strategies, Malaysian Agricultural Research and Development Institute (MARDI), 2005.

[3] Environmental Protection Agency (EPA) Volunteer Stream Monitoring: A Methods Manual, Office of Water, 1997.

[4] Eisakhani, M., Pauzi, A., Karim, O. \& Malakahmad, A., GIS-based Nonpoint Sources of Pollution Simulation in Bertam River, Cameron Highlands. International Journal of Environmental Science and Engineering, 1(3), pp. 131-135, 2009.

[5] Notovny, V., \& Chesters, G., Handbook of Nonpoint Pollution Sources and Management, Litton Educational Publishing Inc., New York, USA, 1981.

[6] Naranjo, E. Denmark Institute of Geography, Lithuania and Klapeida University, Lithuania. Runoff of Nutrients from Minija River Basin. VKI, Hørsholm, Denmark, 1994.

[7] Adroit Consulting Engineers, A study on pollution prevention and water quality improvement program of rivers in Cameron Highlands, National Seminar, HANDOUTS, Government of Malaysia, 2005.

[8] Mogens, H., L40 Pollution Source Assessments, Department of Sanitary Engineering, Technical University of Denmark, Denmark, 1994.

[9] Robertson, D.M. , Graczyk, D.J. , Garrison, P.J., Lizhu, W., Gina, L. \& Bannerman, R., Nutrient Concentrations and Their Relationships to the Biotic Integrity of Wadeable Streams in Wisconsin. US Geological Survey Professional Paper, 1722, 2006.

[10] Hilsenhoff, W., An Improved Biotic Index of Organic Stream Pollution, The Great Lakes Entomologist, 20(1), pp. 31-39, 1987.

[11] Saunders, W. \& Maidment, D., A GIS Assessment of Nonpoint Source Pollution in the San Antonio-Nueces Coastal Basin, Centre for Research in Water Resources, The University of Texas at Austin. Austin, Texas, 1996.

[12] Hanadi, R., Charles, N. \& Phillip, B. Getting to the Nonpoint Source with GIS, Civil Engineering, 63(6), pp. 44-46, 1993.

[13] Chow, V. T., Maidment, D. \& Mays, L., Applied Hydrology, McGraw-Hill Book Co. Singapore, pp. 97-103, 1988.

[14] Benaman, J., Armstrong, N. \& Maidment, D., Modelling of dissolved oxygen in the Houston Ship Channel using WASP5 and Geographic Information Systems, Centre for Research in Water Resources, The University of Texas at Austin. Austin, Texas, 1996.

[15] http://www.met.gov.my/english/publication/mwb07.html 